\title{
Developmental Changes in Gene Expression Drive Accumulation of Lycopene and $\beta$-Carotene in Watermelon
}

\author{
Nan Wang ${ }^{1}$, Shi Liu', Peng Gao, and Feishi Luan³ \\ Horticulture College, Northeast Agricultural University, No. 59 Mucai Street, Harbin 150030, \\ Heilongjiang Province, China; and Key Laboratory of Biology and Genetic Improvement of \\ Horticulture Crops (Northeast Region), Ministry of Agriculture, No. 59 Mucai Street, Harbin 150030, \\ Heilongjiang Province, China \\ Angela R. Davis ${ }^{2}$ \\ South Central Agricultural Research Laboratory, Agricultural Research Service, U.S. Department of \\ Agriculture, Hwy. 3 West, Lane, OK 74555-0159
}

\begin{abstract}
AdDitional INDEX words. Citrullus lanatus, carotenoid, anabolism, flesh color, fruit development
Abstract. Citrullus lanatus (watermelon) is an excellent daily source of dietary lycopene and $\beta$-carotene. To investigate the transcriptional regulation of carotenoid biosynthesis genes relative to lycopene and $\beta$-carotene accumulation in watermelon fruit, six watermelon accessions with different flesh colors were examined in this study: white-fleshed PI 459074, pale-yellow-fleshed 'Cream of Saskatchewan', light-pink-fleshed PI 482255, orange-yellowfleshed 'WM-Clr-1', and red-fleshed 'LSW177' and 'MSW28'. The expression patterns of eight genes (PSY1, PSY2, $P D S, Z D S, C R T I S O, L C Y B, N C E D 1$, and $N C E D 7)$ involved in lycopene and $\beta$-carotene biosynthesis and biodegradation were analyzed. The results confirmed the accumulation of large quantities of lycopene in red-fleshed 'LSW177' and 'MSW28', reflecting the elevated expression of PSY1 and the low transcriptional expression of $N C E D 1$. The relative expression levels of $N C E D 1$ likely play an important role in the color development of the light-pinkfleshed PI 482255, whereas the reduced transcriptional expression of PSY1 and the increased expression of NCED1 appear to be the main factors contributing to the formation of white flesh in the fruit of PI 459074. Low transcriptional expression of PSY1 results in the pale-yellow flesh of the 'Cream of Saskatchewan' fruit.
\end{abstract}

Flesh color is an essential agronomic characteristic of watermelon (Hashizume et al., 2003). Eight different watermelon flesh colors have been defined to date: white, pale yellow, canary yellow, salmon yellow, orange, crimson red (red), scarlet red, and green (Zhao et al., 2013). This wide range of color distribution reflects the carotenoid composition and content of the fruit (Tadmor et al., 2005). Red-fleshed watermelon contains the highest carotenoid levels, with lycopene as the most abundant carotenoid. In contrast, white-fleshed watermelon contains only trace amounts of carotenoids. Orange-fleshed watermelon contains $\beta / \zeta$-carotene, prolycopene, and phytoene, and yellow-fleshed watermelon mainly contains violaxanthin and/or neoxanthin, with some accessions containing lutein (Yuan et al., 2015). The multiple gene loci that control watermelon flesh color remain to be fully elucidated.

Lycopene, a major pigment in the flesh of red watermelon, has attracted much attention in epidemiological and nutritional studies. Pathology studies have shown that increased lycopene intake reduces the risks of lung, digestive, breast, endometrial, and prostate cancers (Charnow, 2014; Chen et al., 2014; Sharoni et al., 2012; Tapiero et al., 2004; Van Breemen and Pajkovic, 2008). In addition, lycopene is a powerful antioxidant that reduces the risk

Received for publication 15 Jan. 2016. Accepted for publication 4 May 2016. This research was financially supported by the National Natural Science Foundation of China (31572144) and the China Agriculture Research System (CARS-26-02).

${ }^{1}$ These authors contributed equally to this work.

${ }^{2}$ Current address: HM Clause, 9241 Mace Boulevard, Davis, CA 95618.

${ }^{3}$ Corresponding author. E-mail: luanfeishi@neau.edu.cn. of coronary heart disease (Berman et al., 2015; Rao and Agarwal, 2000). As the most potent dietary precursor of vitamin A, $\beta$-carotene is an essential nutrient for humans and animals (Grune et al., 2010), and deficiency results in xerophthalmia, blindness in humans, and even premature death in children (Botella-Pavia and Rodriguez-Concepcion, 2006). $\beta$-Carotene can be used as an effective oral protectant against sunburn (Stahl and Sies, 2005), and lycopene and $\beta$-carotene are the primary carotenoids in human skin and plasma (Scarmo et al., 2010). Humans and most animals must obtain lycopene and $\beta$-carotene via dietary intake because they cannot otherwise synthesize these carotenoids (Arimboor et al., 2015; Berman et al., 2015).

Consumed as either a dessert or functional food (food that potentially has a positive effect on health beyond basic nutrition) to replace some medicine for overall health (Rockville, 2015), watermelon has been reported as a preferred source of lycopene and $\beta$-carotene for humans (Perkins-Veazie et al., 2012). Solanum lycopersicum (tomato) is a rich source of lycopene. However, as heat is required to promote tomato lycopene bioavailability (Edwards et al., 2003), the bioavailability of this source is limited by the necessity of such processing (Hwang et al., 2012). Previous studies have reported that the dietary intake of watermelon juice could significantly increase the lycopene and $\beta$-carotene concentrations in human plasma (Edwards et al., 2003).

The lycopene content in watermelon is influenced by the maturity, genotype, and ploidy levels (Perkins-Veazie et al., 2002, 2006). Lycopene has been reported as the most abundant pigment in red-fleshed watermelon, with an abundance of 
$\approx 60 \%$ more in this fruit than in tomato, whereas $\beta$-carotene is a secondary carotenoid (Holden et al., 1999; Zhao et al., 2013). Lycopene is the predominant carotenoid in pink-fleshed watermelon, and the lycopene content in yellow-fleshed watermelon is extremely low (Yoo et al., 2012).

A complete understanding of the molecular and genetic mechanisms controlling carotenoid accumulation is fundamental in targeted breeding for increasing the provitamin A carotenoid content through genetic engineering and breeding in watermelon (Bai et al., 2011; Berman et al., 2015).

The carotenoid biosynthesis pathway in higher plants has been well described for decades (Fig. 1). The first step is a condensation reaction in which two molecules of geranylgeranyl pyrophosphate are catalyzed by phytoene synthase (PSY) to form phytoene. Phytoene is then catalyzed to cis-lycopene by phytoene desaturase (PDS) and $\zeta$-carotene desaturase (ZDS) via phytofluene and $\zeta$-carotene. The yellow product cislycopene is subsequently converted to red translycopene by the two cis-trans isomerases Z-ISO and CRTISO (Cazzonelli and Pogson, 2010). Cyclization of lycopene is a branching point of the carotenoid biosynthetic pathway, either adding an $\epsilon$-ring and a $\beta$-ring to yield $\alpha$-carotene via cyclization by lycopene $\beta$-cyclase (LCYB) and lycopene $\epsilon$-cyclase (LCYE) or adding two $\beta$-rings to produce $\beta$-carotene from cyclization by LCYB (Lu and Li, 2008; Tuan et al., 2011). Thereafter, two hydroxylases, $\beta$-ring hydroxylase (CHYB) and $\alpha$-ring hydroxylase (CHXE), hydroxylate $\alpha$-carotene to form lutein. In addition, $\beta$-carotene is hydroxylated into zeaxanthin by a carotene hydroxylase (CHYB). Further epoxidation of zeaxanthin to violaxanthin is catalyzed by zeaxanthin epoxidase (ZEP), which is then converted into neoxanthin by neoxanthin synthase (GómezGarcía and Ochoa-Alejo, 2013; Lu and Li, 2008). Both violaxanthin and neoxanthin are precursors of abscisic acid (ABA) in reactions catalyzed by carotenoid cleavage dioxygenases (CCDs) and 9-cisepoxycarotenoid dioxygenases (NCEDs) (Walter and Strack, 2011).

In tomato, PSY and $L C Y B$ are regarded as the key genes responsible for the accumulation of lycopene in tomato fruit. When the transcription of $P S Y$ and $L C Y B$ is inhibited in tomato, the accumulation of lycopene and $\beta$-carotene were significantly inhibited (Bu et al., 2014). Three isoforms of the PSY gene have been reported in watermelon: $P S Y-A, P S Y-B$, and $P S Y-C$ (Bang et al., 2006). Similarly, two $P S Y$ family genes, Cla009122 and Cla005425, have been identified in 'Dumara', showing expression patterns similar to that of $P S Y-1$ and $P S Y-2$ in tomato, respectively (Grassi et al., 2013). The increased accumulation of lycopene and $\beta$-carotene in red- and pink-fleshed watermelon might reflect the decreased gene expression of $L C Y B$ and $C H Y B$. White-fleshed accession results from a reduction of the metabolic flux in the carotenoid pathway (Kang et al., 2010). $P S Y$ and $L C Y B$ are considered key genes controlling lycopene accumulation in red-fleshed watermelon (Guo et al., 2011). Nevertheless, a recent study suggested alternative hypotheses concerning the key genes leading to carotenoid accumulation in red- and pink-fleshed watermelon (Lv et al., 2015). Instead of $L C Y B$, the upregulation of carotenoid biosynthesis genes, including geranylgeranyl pyrophosphate synthase and PSY, and the downregulation of NCEDs have been reported as major factors in the accumulation of carotenoids in red- and pinkfleshed watermelon. The lack of a precursor metabolite supply and high transcript levels of NCED result in small quantities of carotenoids in yellow and white fruit. The $L C Y B$ gene has been

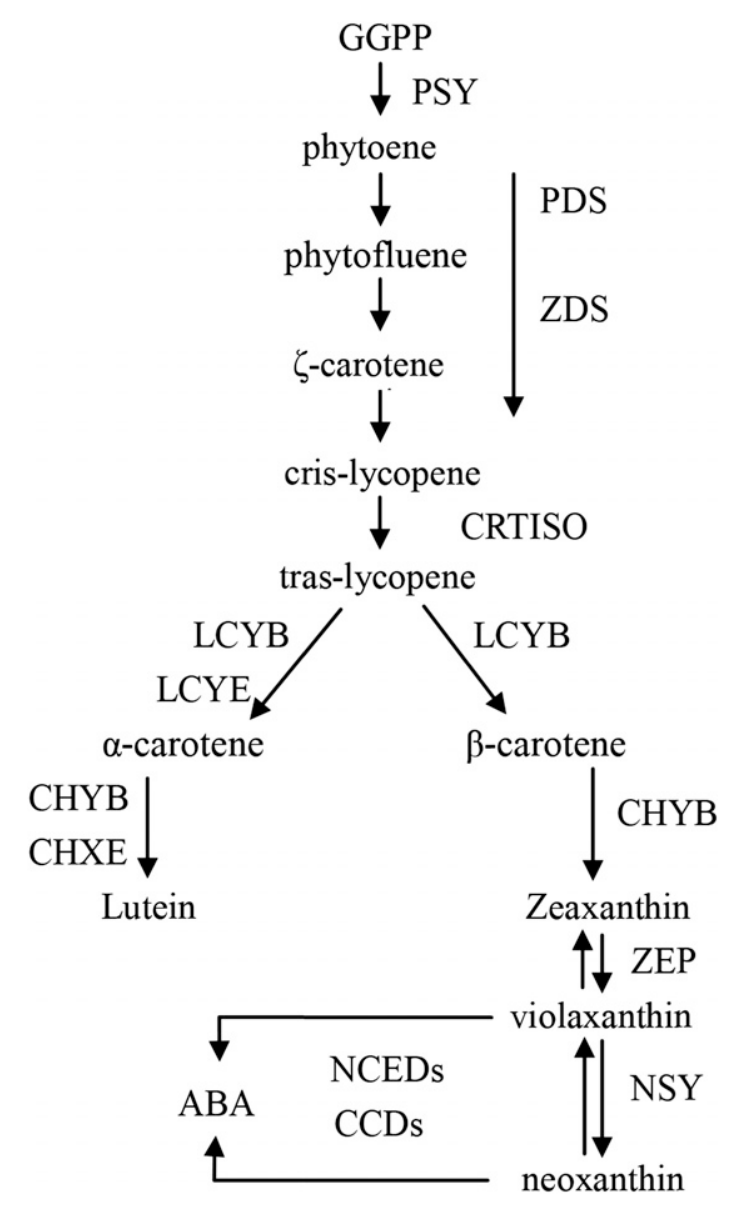

Fig. 1. Simplified schematic of plant carotenoid biosynthesis.

reported as a major quantitative trait locus (QTL) that could increase the lycopene content in watermelon (Liu et al., 2015). Obviously, these studies are not completely consistent regarding how they determined the key genes that controlled lycopene and $\beta$-carotene in watermelon. Moreover, few studies have investigated the accumulation of lycopene and $\beta$-carotene in relation to the transcriptional regulation of carotenoid biosynthesis genes during the development of orange-yellowfleshed watermelon.

In the present study, lycopene and $\beta$-carotene contents were determined in six different watermelon accessions at seven time points during fruit development. In addition, the expression patterns of eight genes (PSY1, PSY2, PDS, ZDS, CRTISO, $L C Y B, N C E D 1$, and NCED7) involved in the carotenoid pathway were characterized to investigate the transcriptional regulation of key carotenoid biosynthesis genes in relation to lycopene and $\beta$-carotene accumulation during watermelon development and ripening.

\section{Materials and Methods}

Plant materials and tissue sampling. Six different fleshcolored watermelon accessions (white-fleshed PI 459074, paleyellow-fleshed 'Cream of Saskatchewan', light-pink-fleshed PI 48225, orange-yellow-fleshed 'WM-Clr-1', red-fleshed 'LSW177', and 'MSW28') were used in this study. The 5-weekold seedlings from each watermelon accession were transplanted in 
the greenhouse at the Xiangfang Agricultural Experiment Station of Northeast Agricultural University, Harbin, China, in May 2014, and 30 plants were grown for each accession. All of the plants were cultivated $\approx 80 \mathrm{~cm}$ apart in rows, leaving $\approx 50 \mathrm{~cm}$ of space between the rows. The plants were treated uniformly regarding irrigation and other management.

For fruit collection, watermelon plants were tagged during hand pollination and harvested on defined days after pollination [8-d intervals until $56 \mathrm{~d}$ after pollination (DAP)]. At least three injury-free fruit were collected at each developmental stage for further analysis. The samples were cut longitudinally, and the color of the flesh was immediately photographed. Flesh samples for ribonucleic acid (RNA) extraction were obtained from the heart of one half of the fruit, which was deseeded and immediately frozen in liquid nitrogen before storing at $-80{ }^{\circ} \mathrm{C}$ until RNA extraction. Flesh samples for the lycopene and $\beta$-carotene analysis were obtained from the other half of the fruit in the corresponding area, frozen in liquid nitrogen and stored at $-80{ }^{\circ} \mathrm{C}$ until lycopene and $\beta$-carotene analysis.

Pigment extraction and high-PERformance LiQuid CHROMATOGRAPHY ANALYSIS. The deseeded flesh samples at each fruit stage were frozen at $-80{ }^{\circ} \mathrm{C}$ and rapidly homogenized using a homogenizer (Bio-Gen PRO200; PRO Scientific, Oxford, CT). Three grams of homogenized flesh at different fruit stages were used for carotenoid extraction. The carotene extraction method was performed according to Liu et al. (2015), with some modifications. The samples were dissolved in the mobile phase [2 methyl alcohol : 5 acetonitrile : 3 dichloromethane (by volume)] and filtered through a $0.22-\mu \mathrm{m}$ organic nylon filter. High-performance liquid chromatography (HPLC) analysis was performed using an HPLC instrument (Waters, Milford, MA) equipped with a binary HPLC pump (1525, Waters), an autosampler (2707, Waters) and a photodiode array detector (2998, Waters) with a $4.6 \times 250-\mathrm{mm}$, 5- $\mu$ m column (LC ZORBAX SB-C18; Agilent Technologies, Palo Alto, CA). The column temperature was $25^{\circ} \mathrm{C}$, and the column flow rate was $1.00 \mathrm{~mL} \cdot \mathrm{min}^{-1}$. Carotene was detected at $472 \mathrm{~nm}$, as identified based on retention time compared with authenticated standards (lycopene and $\beta$-carotene purchased from SigmaAldrich, St. Louis, MO) at a concentration of $0.20 \mathrm{mg} \cdot \mathrm{mL}^{-1}$; values were quantified according to standard curves. All of the samples were analyzed in triplicate.

RNA ISOLATION. Samples of watermelon flesh obtained at seven time points during fruit development $(8,16,24,32,40$,
48, and 56 DAP) were used for RNA isolation. Total RNA was isolated from freeze-dried flesh samples (using Heto PowerDry LL3000; Thermo Fisher Scientific, Waltham, MA) obtained at each developmental stage using the TRIZOL reagent (Invitrogen, Carlsbad, CA). The quality and quantity of RNA were determined using a spectrophotometer (SMA 4000; Merinton, Ann Arbor, MI). In addition, the integrity of RNA was examined using $1 \%(\mathrm{w} / \mathrm{v})$ denaturing agarose gel electrophoresis. Good-quality RNAs with $\mathrm{A}_{260}$ (the absorbance of the nucleic acid at $260 \mathrm{~nm}$ ) to $\mathrm{A}_{280}$ (the absorbance of protein at $280 \mathrm{~nm}$ ) ratios greater than 1.80 were selected, with no discernable degradation observed.

Complementary DNA synthesis. Complementary deoxyribonucleic acids (cDNAs) were synthesized from $\approx 0.5 \mu \mathrm{g}$ of total RNA using the ReverTra Ace qPCR RT Master Mix with gDNA Remover (code no. FSQ-301; Toyobo, Osaka, Japan). A single step was conducted to remove genomic DNA (gDNA) according to the instructions. To remove gDNA, $0.5 \mu \mathrm{g}$ of RNA and $2 \mu \mathrm{L}$ of $4 \times$ DN Master Mix (with gDNA Remover) were mixed with RNase-free $\mathrm{H}_{2} \mathrm{O}$ to achieve a total volume of $8 \mu \mathrm{L}$ and incubated at $37^{\circ} \mathrm{C}$ for 5 min. cDNA was synthesized using an $8 \mu \mathrm{L}$ gDNA removing reaction and $2 \mu \mathrm{L}$ of $5 \times \mathrm{RT}$ Master Mix II according to the instructions.

QuANTITATIVE REAL-TIME POLYMERASE CHAIN REACTION ANALYSIS. For the eight genes involved in carotenoid metabolism (PSY1, PSY2, PDS, ZDS, CRTISO, LCYB, NCED1, and NCED7) and ClYLS8 (yellow-leaf-specific protein 8), the reference gene (Kong et al., 2014) and specific primers were designed using the Premier 6.0 Software based on Grassi et al. (2013). The primer sequences, amplicon sizes, and accession numbers are shown in Table 1. The transcript levels of the genes were evaluated by quantitative real-time polymerase chain reaction (qRT-PCR) using the Applied Biosystems 7300 Fast Real-Time System (Applied Biosystems, Foster City, CA). For qRT-PCR, the Tiangen Real Master Mix containing SYBR Green (code no. FP202; Tiangen, Beijing, China) was used according to the instructions. qRT-PCR was performed using $1 \mu \mathrm{L}$ of diluted cDNA (10 ng of total RNA $), 1 \mu \mathrm{L}\left(2 \mu \mathrm{mol} \cdot \mathrm{L}^{-1}\right)$ of each primer, $9 \mu \mathrm{L}$ of $2.5 \times$ Real Master Mix (with $20 \times$ SYBR Solution) and RNase-free double-distilled $\mathrm{H}_{2} \mathrm{O}$ to reach a final volume of $20 \mu \mathrm{L}$. The cDNA samples were all analyzed in three technical repeats (the SES were calculated from three replicates for each sample). The amplification included one cycle of $95^{\circ} \mathrm{C}$

Table 1. Primers used for quantitative real-time PCR analysis of gene expression in six watermelon accessions at seven time points during fruit development.

\begin{tabular}{|c|c|c|c|c|}
\hline Gene & $\begin{array}{c}\text { CuGenDB } \\
\text { accession no. }\end{array}$ & Forward primer & Reverse primer & $\begin{array}{l}\text { Amplicon } \\
\text { size (bp) }\end{array}$ \\
\hline$\overline{P S Y 1}$ & Cla009122 & CCCAAATTCCCGATTCTTCCAGATTCT & ACAGAGCCATATCCACCTTCACAGA & 139 \\
\hline PSY2 & $\mathrm{Cla} 005425$ & AAGGGTCTATGAAGTTGTGCTGAAG & AAGCATTAGGTCCATCCACGAG & 308 \\
\hline$P D S$ & $\mathrm{Cla} 010898$ & GTGTTGGCTCGGTCGCTTGT & GAGAGTGGTAGTTGTAGTGGCAGATT & 194 \\
\hline$Z D S$ & Cla003751 & CGCTGTATGCTTACTATCTTCTCGTTGT & CCTCTGTCCGTGATATACTTCCTTATGG & 125 \\
\hline CRTISO & Cla017593 & CTTCTTCGGCTACTCGGTTGGTT & ACTATTGCGGCACGACGGATAT & 82 \\
\hline$L C Y B$ & Cla005011 & GAGCATTGAAGAGGATGAGCATTGTG & CGCTGCTAGAGTTCTTGCTACCATAT & 142 \\
\hline NCED 1 & Cla009779 & CTGCTTCCCTCGCCTTAG & СТTCTTCCACTAGCGAGACCATCCT & 121 \\
\hline NCED7 & Cla005404 & CCAACCCACTTCACGAACCC & CGGCAAGCGTAACTAACACC & 106 \\
\hline ClYLS8 & Cla020175 & AGAACGGCTTGTGGTCATTC & GAGGCCAACACTTCATCCAT & 83 \\
\hline
\end{tabular}

$\mathrm{PCR}=$ polymerase chain reaction; $\mathrm{bp}=$ base pair.

${ }^{\mathrm{z} C u c u r b i t}$ Genomics Database (Grassi et al., 2013). 

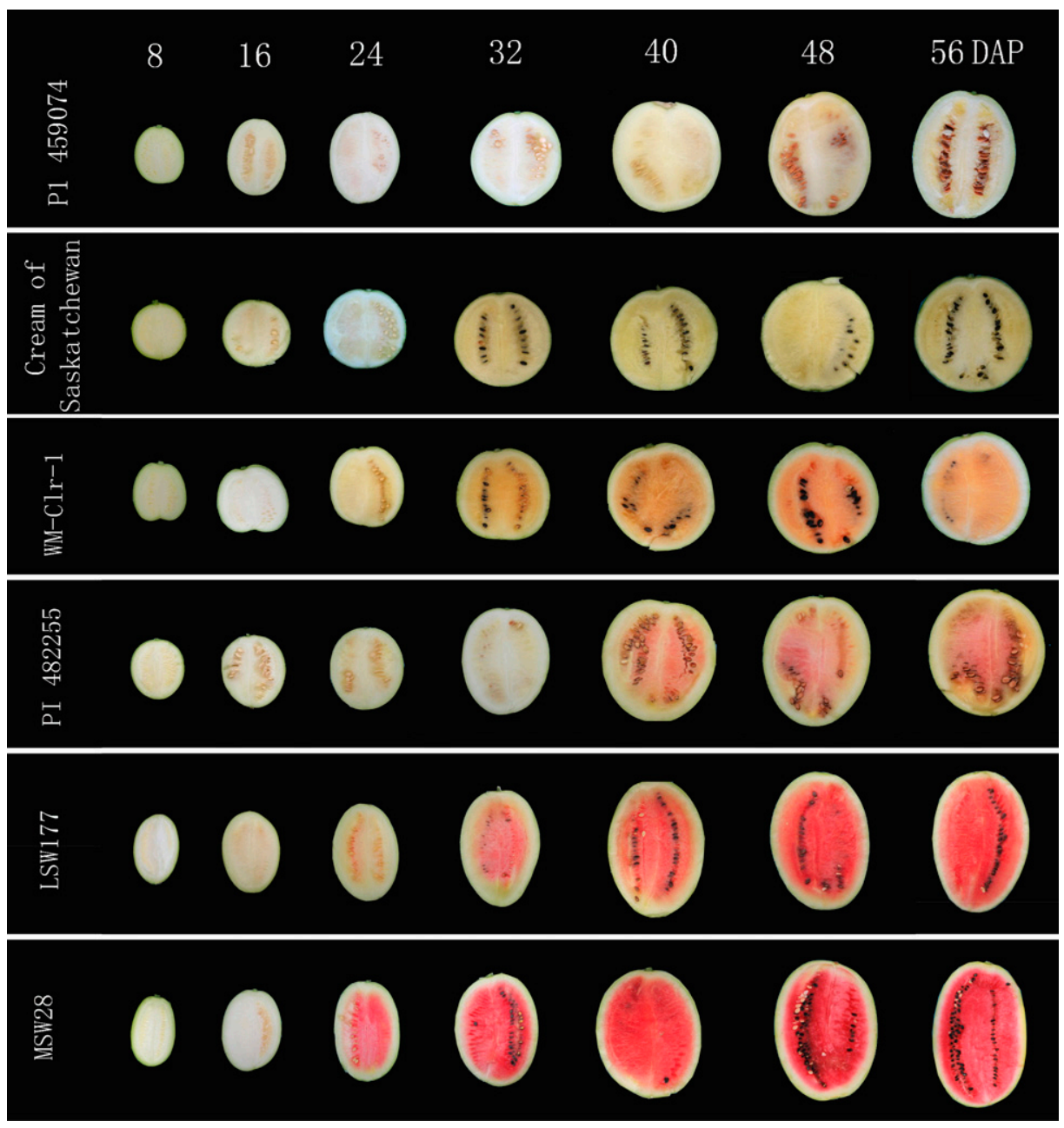

Fig. 2. Photographs of fruits from six watermelon accessions (PI 459074, 'Cream of Saskatchewan', 'WM-Clr-1', PI 482255, 'LSW177', and 'MSW28') with different flesh colors at seven time points (8, 16, 24, 32, 40, 48, and $56 \mathrm{~d}$ after pollination) during fruit development.

for $60 \mathrm{~s}$, followed by 40 cycles of $95^{\circ} \mathrm{C}$ for $15 \mathrm{~s}, 60^{\circ} \mathrm{C}$ for $30 \mathrm{~s}$, and $68{ }^{\circ} \mathrm{C}$ for $30 \mathrm{~s}$. At the end of the reaction, a dissociation curve was generated. Amplification of the specific transcripts was confirmed as the appearance of a single peak in the melting curve analysis following the completion of the amplification reaction. Negative controls with no cDNA templates were conducted in all runs to screen for potential contamination. The relative expression was analyzed using the $2^{-\Delta \Delta \mathrm{C}_{\mathrm{T}}}$ method (Livak and Schmittgen, 2001), and a sample from each watermelon accession at 8 DAP was used for calibration.

\section{Results and Discussion}

FLESH COLOR AT SEVEN TIME POINTS DURING WATERMELON FRUIT DEVELOPMENT. The development of fruit flesh color in six watermelon accessions is shown in Fig. 2.

The fruit flesh of 'LSW177' and 'MSW28' remained white during the early developmental stages (0-16 DAP), turned pink at 24 DAP and then rapidly turned red. In contrast, the flesh of 'LSW177' turned pink at 32 DAP and turned red at 40 DAP. For PI 459074, the flesh color remained unchanged during the entire development and maturation period. The flesh color of PI 482255 did not change until 40 DAP. The flesh of 'WM-Clr-1' was white during the early stages of development, and the distinctive orange-yellow flesh color of this cultivar rapidly developed from 24 to 40 DAP, with minor variations thereafter. The pale-yellow flesh of 'Cream of Saskatchewan' followed a color change pattern similar to that of 'WM-Clr-1'.

Changes in the aCcumulation OF LYCOPENE AND $\beta$-CAROTENE IN WATERMELON AT SEVEN TIME POINTS DURING FRUIT DEVELOPMENT. The HPLC results of the lycopene and $\beta$-carotene contents of the six accessions obtained at seven time points during watermelon fruit development are shown in Fig. 3 and in Supplemental Table 1.

The accumulation of lycopene and $\beta$-carotene in the flesh of watermelon fruit dramatically increased in parallel with the accumulation of carotenoids during the development of red-fleshed cultivars. The amount of lycopene varied during fruit maturation from the white to orange or red stages. Lycopene was detectable in 'MSW28' at $16 \mathrm{DAP}\left(0.39 \mu \mathrm{g} \cdot \mathrm{g}^{-1}\right)$ and in 'LSW 177' at 24 DAP $\left(1.12 \mu \mathrm{g} \cdot \mathrm{g}^{-1}\right)$ and then markedly increased in 'MSW28' (from 5.76 to $\left.58.68 \mu \mathrm{g} \cdot \mathrm{g}^{-1}\right)$ and in 'LSW 177' (from 7.90 to $40.77 \mu \mathrm{g} \cdot \mathrm{g}^{-1}$ ) from 24 to $40 \mathrm{DAP}$, followed by slight decreases to $54.30 \mu \mathrm{g} \cdot \mathrm{g}^{-1}$ and $33.40 \mu \mathrm{g} \cdot \mathrm{g}^{-1}$, respectively, from 40 to 56 DAP. However, the concentrations of $\beta$-carotene in red-fleshed 'LSW177' and 'MSW28' were much lower than those of lycopene. $\beta$-Carotene was undetectable in 'LSW177' until 32 DAP $\left(0.11 \mu \mathrm{g} \cdot \mathrm{g}^{-1}\right)$ and then slowly increased to $4.15 \mu \mathrm{g} \cdot \mathrm{g}^{-1}$ by 56 DAP. In 'MSW28', $\beta$-carotene was detected at $32 \mathrm{DAP}\left(1.87 \mu \mathrm{g} \cdot \mathrm{g}^{-1}\right)$ and peaked at 56 DAP $\left(6.70 \mu \mathrm{g} \cdot \mathrm{g}^{-1}\right)$. Evidence has shown that lycopene is the predominant pigment responsible for red-colored flesh in watermelon cultivars; however, the levels of lycopene vary (PerkinsVeazie et al., 2006), ranging from 33.80 to $82.30 \mu \mathrm{g} \cdot \mathrm{g}^{-1}$ in seeded diploid red-fleshed cultivars. The lycopene contents were maximized in these two genotypes at 40 DAP and then gradually decreased until 56 DAP. Lv et al. (2015) showed that lycopene accumulation peaked at 30 DAP in red-fleshed 'NC66' and subsequently decreased. This effect could reflect the fact that the maturation period of NC66 occurred earlier than that of the cultivars examined in the present study (LSW177 and MSW28).

The lycopene content in the light-pink-fleshed PI 482255 at 56 DAP was about one-third of that in 'LSW177' and a quarter of that in 'MSW28'. Lycopene accumulation was detectable in PI 482255 at 32 DAP $\left(0.61 \mu \mathrm{g} \cdot \mathrm{g}^{-1}\right)$ and reached $12.60 \mu \mathrm{g} \cdot \mathrm{g}^{-1}$ at 56 DAP. The $\beta$-carotene content in PI 482255 was extremely low, only $0.20 \mu \mathrm{g} \cdot \mathrm{g}^{-1}$ at $56 \mathrm{DAP}$. Although lycopene accumulation 

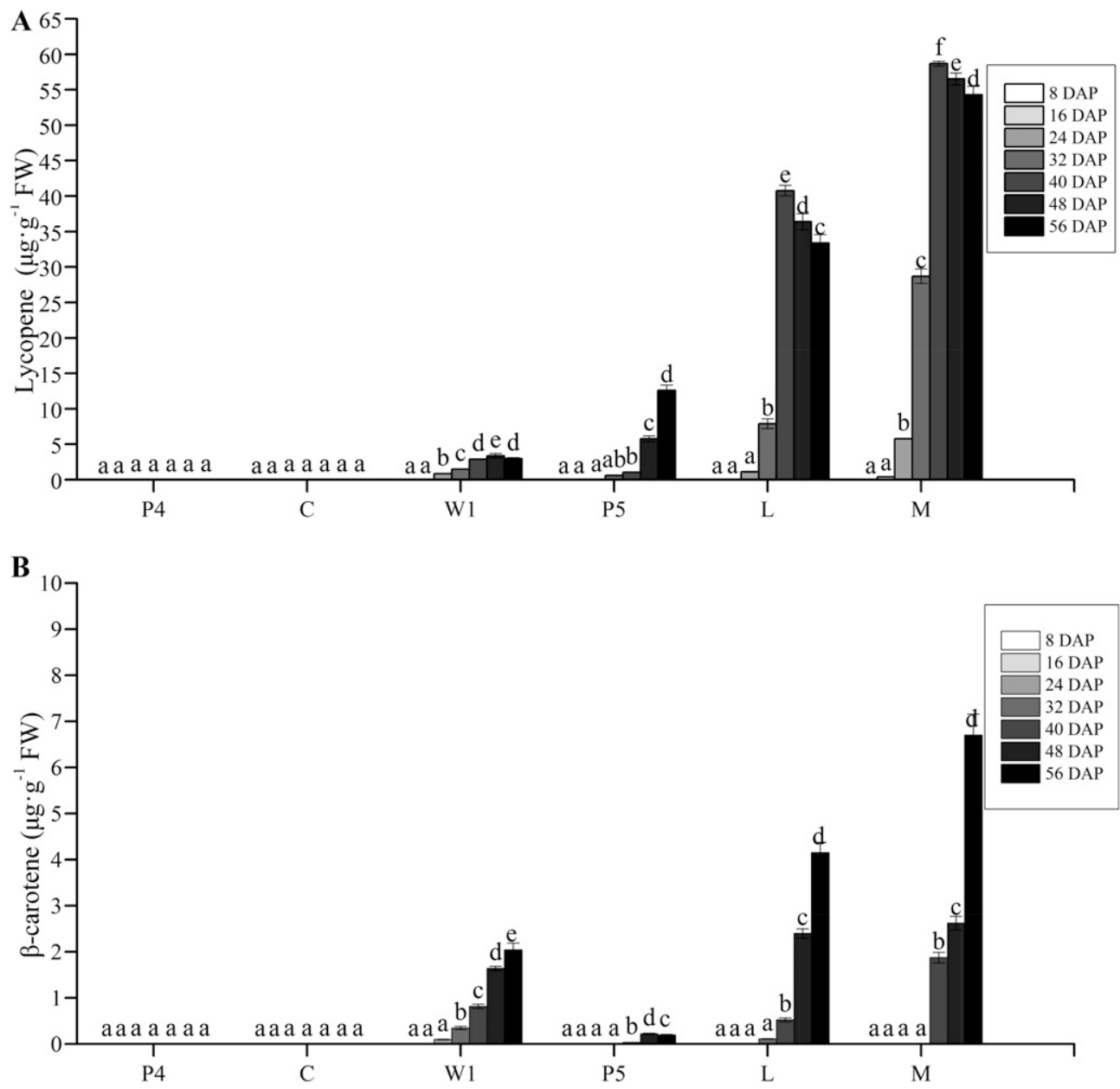

Fig. 3. Accumulation of lycopene (A) and $\beta$-carotene (B) in six watermelon accessions [PI 459074 (P4), 'Cream of Saskatchewan' (C), 'WM-Clr-1' (W1), PI 482255 (P5), 'LSW177' (L), 'MSW28' (M)] with different flesh colors at seven time points $(8,16,24,32,40$, 48, and $56 \mathrm{~d}$ after pollination) during fruit development. The bars represent the means $\pm \mathrm{SD}(\mathrm{n}=3)$. Means with different lowercase letters differed significantly among the development stages in the same accession $(P \leq 0.05)$.

in this material was low, it was sufficient to give the flesh a visible pink color.

Lycopene accumulation was higher than $\beta$-carotene accumulation in orange-yellow-fleshed cultivar WM-Clr-1, indicating that the distinct orange color in this cultivar does not reflect $\beta$-carotene accumulation. We observed one carotenoid in this cultivar, which was present at much higher concentrations than the lycopene and $\beta$-carotene contents detected. Only two types of orange-fleshed watermelon accessions have been identified thus far: one type, such as 'NY162003', is predominantly colored due to $\beta$-carotene accumulation; the other type is primarily colored by prolycopene and $\zeta$-carotene (Tadmor et al., 2005). On the basis of these results, we deduced that the distinct pigment detected in this watermelon likely results from prolycopene or $\zeta$-carotene, which endow 'WM-Clr-1' with its distinct color.

No lycopene or $\beta$-carotene was detected in white-fleshed PI 459074 or pale-yellow-fleshed 'Cream of Saskatchewan'. Similarly, Lv et al. (2015) detected no lycopene or $\beta$-carotene in white-fleshed 'ZXG507' or yellow-fleshed 'ZXG381'. These results suggest that the lycopene and $\beta$-carotene contents in these cultivars are below the detection limits of the HPLC method used in this study.
EXPRESSION PATTERNS OF METABOLIC CAROTENOID GENES IN WATERMELON AT SEVEN TIME POINTS DURING FRUIT DEVELOPMENT. To examine the regulation of lycopene and $\beta$-carotene biosynthesis in different types of watermelon with different flesh colors and to determine how differences in gene expression may be associated with differential changes in lycopene and $\beta$-carotene accumulation, eight genes of the carotenoid biosynthetic pathway were analyzed in different samples collected from the same fruit used for HPLC analysis. The relative transcription levels of genes involved in carotenoid metabolism were analyzed using qRT-PCR during watermelon fruit development as shown in Fig. 4 and in Supplemental Table 2.

Many horticultural crops, such as citrus fruit (Citrus sp.), peach (Prunus persica), tomato, chili pepper (Capsicum sp.), pumpkin (Cucurbita moschata), and watermelon, are primarily colored by carotenoids (Brandi et al., 2011; Gómez-García and Ochoa-Alejo, 2013; Nakkanong et al., 2012; Tadmor et al., 2005; Zhang et al., 2012; Zhao et al., 2013). The regulation of carotenoid accumulation and transcription levels of the genes that encode carotenoid biosynthesis during fruit development and ripening have been studied in many plants (Kato et al., 2004; Nakkanong et al., 2012; Tuan et al., 2011; Wei et al., 2014). The results of these studies suggest that the transcriptional 

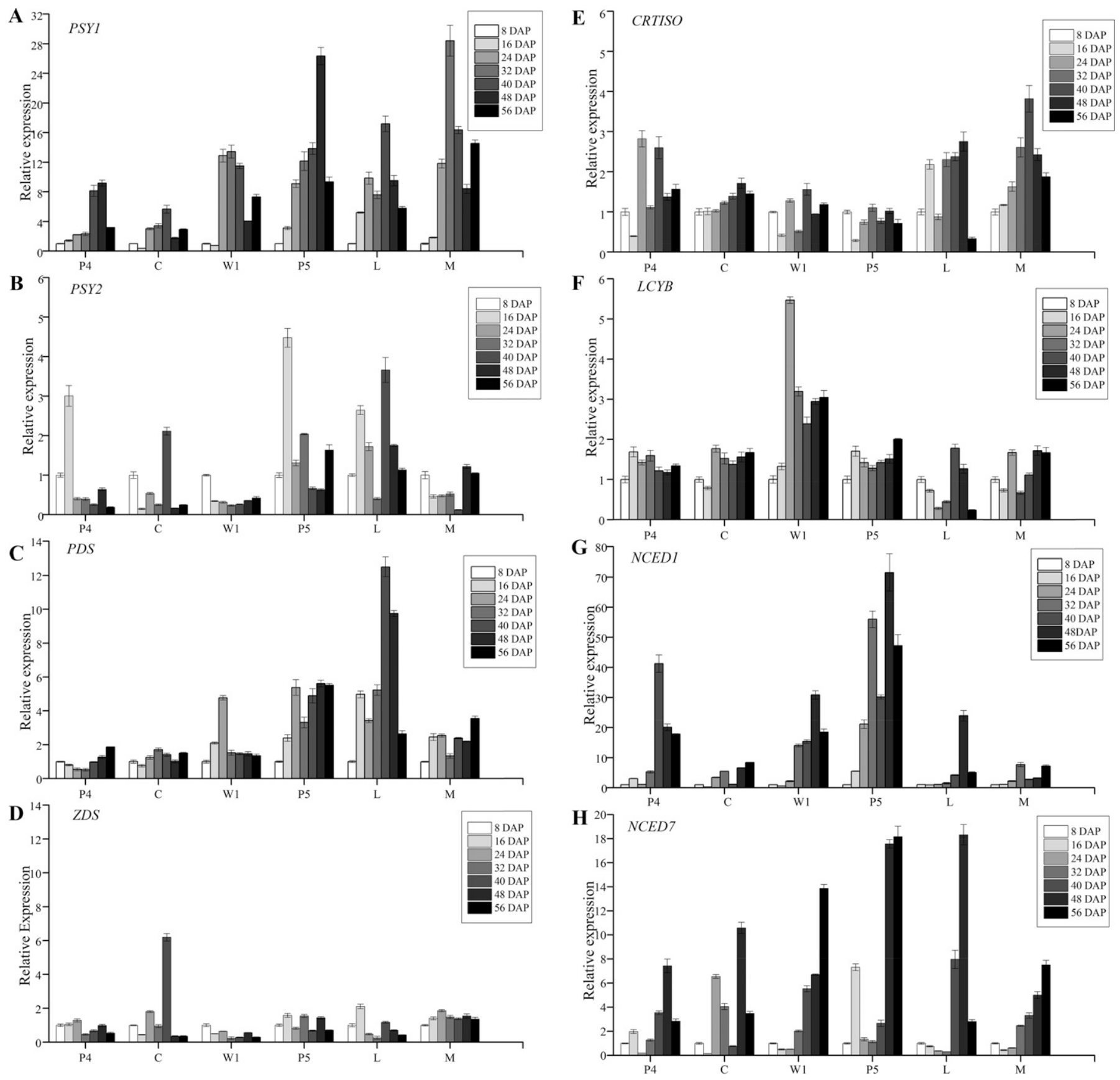

Fig. 4. The transcription levels of eight carotenogenesis genes in six watermelon accessions [PI 459074 (P4), 'Cream of Saskatchewan' (C), 'WM-Clr-1' (W1), PI 482255 (P5), 'LSW177' (L), 'MSW28' (M)] with different flesh colors at seven time points $(8,16,24,32,40,48$, and $56 \mathrm{~d}$ after pollination) during fruit development $(\mathbf{A}-\mathbf{H})$. The bars represent the means $\pm \mathrm{SD}(\mathrm{n}=3)$.

regulation of gene expression is a key mechanism for regulating carotenogenesis.

In all of the fruit, the expression of the upstream carotenogenesis gene PSY1 progressively increased 16 DAP, was maximal at 32,40 , or 48 DAP and slightly decreased thereafter. In addition, $P S Y 1$ transcripts were much more abundant than PSY2 transcripts in all materials at all seven time points during fruit development. The expression of the two NCED genes involved in ABA biosynthesis in fruit with different colors of flesh increased during maturation and showed different expression patterns.
PSY1 exhibited different expression patterns among the accessions with different flesh colors, which could be divided into three groups based on the relative expression of PSY1. The transcription levels were much lower in white-fleshed PI 459074 and light-yellow-fleshed 'Cream of Saskatchewan' than in the other accessions. In contrast, PSY1 transcripts were highly expressed in light-pink-fleshed PI 482255 and red-fleshed 'LSW177' and 'MSW28'. Orange-yellow-fleshed 'WM-Clr-1' showed intermediate levels of expression. These results indicated that PSY1 might play an important role in carotenoid accumulation in watermelon. In some plants, $P S Y$ 
has been considered to be a key limiting step in carotenoid biosynthesis. PSY transgenic tomato, which was generated using the bacterium Erwinia uredovora, contains 1.8- and 2.2-fold higher levels of lycopene and $\beta$-carotene, respectively, compared with the control (Fraser et al., 2002). Transformation of rice (Oryza sativa) with PSY dramatically elevated carotenoid accumulation, showing increases of up to 23-fold in golden rice compared with the original carotenoid content (Paine et al., 2005).

PSY1 was found to be highly expressed in red-fleshed cultivars (LSW177 and MSW28) and light-pink-fleshed PI 482255. Statistical analyses indicated that the expression of PSY1 in these accessions differed significantly from that in accessions with other flesh colors from 16 to 56 DAP. The expression of $N C E D 1$ was upregulated at 16 DAP in PI 482255 , followed by a rapid increase and high expression from 24 to 56 DAP. Increased expression of NCED1 in 'LSW177' was not observed until 40 DAP, and the maximum expression of NCED1 in 'LSW177' was achieved at 48 DAP. In 'MSW28', only slight upregulation of NCED1 gene expression was observed during fruit development and ripening. Statistical analyses indicated that $N C E D 1$ expression differs significantly between light-pink-fleshed and red-fleshed accessions at each time point during fruit development from 16 to 56 DAP.

The accumulation of carotenoids was regulated through upstream genes of the carotenogenesis pathway and downstream carotenoid degradation genes. A large quantity of lycopene accumulation was detected in red-fleshed 'LSW177', 'MSW28', and PI 482255 in parallel with the increased expression of PSY1. In addition, transcripts of carotenoid catabolism genes such as NCED1 showed lower expression levels during these stages in 'MSW28' and 'LSW177' compared with PI 482255 at the same stage of fruit development, indicating that upregulation of $P S Y 1$ could result in a flux of metabolic precursors toward lycopene synthesis during watermelon fruit development and ripening. The lower expression of NCED1 blocked downstream degradation, which resulted in the accumulation of lycopene in red-fleshed 'LSW177' and 'MSW28'. Higher levels of lycopene accumulation and PSY1 transcripts were observed in MSW28 than in LSW177, indicating the importance of PSY1 for lycopene accumulation in these two cultivars. Increased $L C Y B$ expression was observed from 40 to 48 DAP, likely resulting in the degradation of lycopene and the increased accumulation of $\beta$-carotene. A similar result was obtained for PSY1 in a transcriptome dynamics study during the fruit development of watermelon cultivar 97103 at four stages [10, 18, 26, and 34 DAP (Guo et al., 2011)]. Lv et al. (2015) showed that the massive accumulation of lycopene in 'NC66' from 18 to 30 DAP coincided with elevated transcriptional expression of biosynthesis genes, such as $P S Y$. We propose that PSYI and NCED1 are important genes for controlling lycopene and $\beta$-carotene accumulation in 'MSW28' and 'LSW177'. Notably, $L C Y B$ transcription decreased during '97103' fruit development and was undetectable at 34 DAP, in contrast with our results. This result suggests that other mechanisms regulate carotenoid accumulation in watermelon. Nogueira et al. (2013) suggested that carotenoid is sequestered into subplastidial compartments and that carotenoid sequestration mechanisms help regulate the carotenoid pathway. This mechanism could have different effects on gene expression in different watermelon materials.
The light-pink-fleshed PI 482255 showed high transcript levels of PSY1, with less lycopene than the red-fleshed 'LSW177' and 'MSW28'. This result might reflect the remarkably high expression of NCED1 observed in this lightpink-fleshed material throughout development and ripening, which suggests that NCEDl could play a significant role in carotenoid catabolism in this light-pink-fleshed watermelon. Similar results have also been shown in tomato, with fruitspecific RNA interference (RNAi)-mediated suppression of SINCED1 increasing the contents of both lycopene and $\beta$-carotene (Sun et al., 2012). We propose that although a large quantity of carotenoid precursors is generated via upregulation of the PSY1 gene in PI 482255, an increase in the quantity of NCED 1 transcripts could accelerate carotenoid degradation and lead to the small amounts of lycopene and $\beta$-carotene accumulation observed in this accession.

In the orange-yellow-fleshed 'WM-Clr-1' accession, PSY1 expression was not as high as that detected in the red- and lightpink-fleshed PI 482255, 'LSW177', and 'MSW28' accessions. However, downstream carotenogenesis genes, such as $L C Y B$, were upregulated, showing higher transcript levels than those detected in red-fleshed 'LSW177' and 'MSW28'. Both NCED1 and NCED7 were upregulated in 'WM-Clr-1' at 32 DAP, and the expression levels of NCED1 in this cultivar were higher than those in red-fleshed 'LSW177' and 'MSW28'. The lower levels of lycopene and $\beta$-carotene accumulation observed in orange-yellow-fleshed 'WM-Clr-1' could be explained by the expression levels of PSY1, LCYB, and NCED1. Low PSY1 expression resulted in lower levels of the precursor metabolite. In contrast, the high $L C Y B$ expression observed during the six time points during fruit development and the high levels of NCED1 transcript resulted in less lycopene and $\beta$-carotene accumulation. In the present study, the expression of CRTISO was detectable in 'WM-Clr-1'. In contrast, Bang (2005) reported undetectable CRTSIO expression in 'Luscious Golden'. Similar results were observed for CRTSIO gene expression in the tomato mutants tangerine ${ }^{3183}$ and tangerine ${ }^{\text {mic }}$ (Isaacson et al., 2002). In tangerine ${ }^{3183}$, CRTISO messenger RNA (mRNA) was undetectable due to a deletion in the promoter region. However, tangerine ${ }^{\text {mic }}$ results from a deletion in the open reading frame, and the mRNA of CRTISO was detectable. Thus, we propose that 'Luscious Golden' is similar to tangerine ${ }^{3183}$ and that 'WM-Clr-1' may be similar to tangerine $^{\text {mic }}$. On the basis of our results, CRTISO may be regulated at the posttranscriptional level in 'WM-Clr-1'.

In white-fleshed PI 459074, the transcript levels of major biosynthetic genes were lower than those in the other coloredflesh cultivars. NCED1 retained higher expression levels than the red-fleshed cultivars at the same time points during fruit development, which indicated that smaller amounts of the metabolic precursors were formed in the colorless accession and that carotenoids were subsequently degraded into colorless compounds via NCED1. A similar result was also observed for the white-fleshed watermelon 'ZXG507' (Lv et al., 2015). The transcripts of PSY in 'ZXG507' were less abundant than the transcripts of $P S Y$ in other colored-flesh at the same development stages, and the expression levels of NCEDs were dramatically higher in the white-fleshed watermelon than in the colored-flesh cultivars. Kang et al. (2010) observed similar results for the white-fleshed cultivar SANBAI.

In general, there are two hypotheses regarding the trace amounts of carotenoids that accumulate in the white tissues of 
higher plants (Clotault et al., 2008). The shortage of carotenoids in white accessions could reflect a lack of precursors, such as phytoene and geranylgeranyl pyrophosphate (Lv et al., 2015). In white carrots (Daucus carota), phytoene synthesis is regarded as a critical restriction that limits the carotenoid pathway (Santos et al., 2005). In C. moschata squash, a low carotenoid content was observed in parallel with the low expression of PSY1 (Nakkanong et al., 2012). Another hypothesis suggests that phytoene and carotenoids in whitefleshed tissues are synthesized and subsequently cleaved into colorless compounds (Kishimoto and Ohmiya, 2009; Ohmiya et al., 2006). Studies of 'Redhaven' peach and its whitefleshed mutant have suggested that carotenoid cleavage dioxygenase 4 (CCD4) plays an important role in white mutant (Brandi et al., 2011). In the present study, the lack of precursor metabolites and the presence of NCED1 were responsible for the undetectable levels of lycopene and $\beta$-carotene in white-fleshed PI 459074. Thus, the $C C D$ gene should be investigated in the white-fleshed watermelon PI 459074 to further understand the absence of carotenoids.

The transcript levels of $P S Y 1$ were markedly low in paleyellow-fleshed 'Cream of Saskatchewan', but $L C Y B$ gene expression in this cultivar was not significantly different from that in the red-fleshed watermelon at the same stage of fruit development. The results of a flesh-color inheritance study suggested that large amounts of lycopene are responsible for the color of red-fleshed watermelon, but canary-yellow flesh is produced with a functional $L C Y B$ gene in the carotenoid pathway (Bang et al., 2010). This result of the present study suggests that low levels of PSY1 transcripts and a functional $L C Y B$ gene are key factors that result in undetectable levels of lycopene and $\beta$-carotene in the pale-yellow-fleshed watermelon 'Cream of Saskatchewan'.

In a previous study, using an $\mathrm{F}_{2}$ population generated from a cross between 'Cream of Saskatchewan' and 'LSW177', $L C Y B$ was identified as the major QTL on chromosome 4 (Liu et al., 2015), dramatically increasing the lycopene content in the examined $F_{2}$ population. In the present study, relative expression of $L C Y B$ did not show statistically significant differences between these two cultivars during fruit development. This result might reflect the three single-nucleotide polymorphisms (SNPs) previously reported in red and yellow cultivars, which were identified by comparing sequences of the full-length cDNA of $L C Y B$ between yellow and red watermelon cultivars. These SNPs could contribute to differences in enzymatic activity in red and yellow watermelon cultivars (Bang et al., 2007) and be responsible for the variations in 'LSW177' and 'Cream of Saskatchewan'. The reduced enzyme activity in 'LSW177' and the upregulation of PSY1 expression could lead to the accumulation of lycopene in 'LSW177'. We hypothesize that the transcriptional regulation of carotenoid gene expression is the main mechanism that controls the biosynthesis and accumulation of specific carotenoids. However, other mechanisms may also be involved. Protein expression, biosynthetic enzyme activity and posttranslational control should also be examined in future studies to understand the mechanisms of carotenoid accumulation in watermelon.

In red-fleshed accessions, $\beta$-carotene accumulation occurred later than lycopene accumulation, and $\beta$-carotene levels increased until 56 DAP. Genes that regulate $\beta$-carotene accumulation have been extensively studied in Cucumis melo. $\mathrm{CmOr}$ is reported to be a gene important for $\beta$-carotene accumulation in melon, but it does not regulate the expression of carotenogenesis genes, and is potentially associated with photosynthetic genes, protein posttranslational regulation and sugar content (Chayut et al., 2015). Interactions among mutant genes were also reported to regulate $\beta$-carotene accumulation in tomato (Andrade et al., 2015). Thus, the mechanisms of $\beta$-carotene accumulation in watermelon need to be further elucidated.

\section{Conclusions}

In this study, changes in the expression patterns of eight carotenogenesis genes and in the accumulation of lycopene and $\beta$-carotene during fruit development and ripening at seven developmental stages in six watermelon accessions with different flesh colors were analyzed. As fruit maturation progressed in red-fleshed LSW177 and MSW28, a simultaneous increase in the relative expression of the PSY1 gene and low expression of $N C E D 1$ led to the massive accumulation of lycopene in these two cultivars. NCEDI could play a significant role in the development and maturation of light-pink-fleshed PI 482255 fruit. The low transcriptional expression of the PSY1 gene and the high expression of NCED1 primarily contributed to the levels of lycopene and $\beta$-carotene accumulation in whitefleshed PI 459074, but were below the detection limit of the HPLC method used in this study. In the pale-yellow-fleshed watermelon 'Cream of Saskatchewan', the lack of detectable lycopene or $\beta$-carotene resulted from low PSY1 transcript levels.

\section{Literature Cited}

Andrade, T.M., W.R. Maluf, C.M. de Oliveira, L.A.A. Gomes, D.C. Santos, R.C. Carvalho, R.J.S. Gonçalves, and Á.C. Gonçalves Neto. 2015. Interaction of the mutant genes $B, o g^{c}, h p$ and $t$ in the coloring of tomato fruit. Euphytica 205:773-783.

Arimboor, R., R.B. Natarajan, K.R. Menon, L.P. Chandrasekhar, and V. Moorkoth. 2015. Red pepper (Capsicum annuum) carotenoids as a source of natural food colors: Analysis and stability-A review. J. Food Sci. Technol. 52:1258-1271.

Bai, C., R.M. Twyman, G. Farré, G. Sanahuja, P. Christou, T. Capell, and C. Zhu. 2011. A golden era-pro-vitamin A enhancement in diverse crops. In Vitro Cell. Dev. Biol. Plant 47:205-221.

Bang, H. 2005. Environmental and genetic strategies to improve carotenoids and quality in watermelon. PhD Diss.,Texas A\&M Univ., College Station.

Bang, H., A.R. Davis, S. Kim, D.I. Leskovar, and S.R. King. 2010. Flesh color inheritance and gene interactions among canary yellow, pale yellow, and red watermelon. J. Amer. Soc. Hort. Sci. 135:362368.

Bang, H., S. Kim, D. Leskovar, and S. King. 2007. Development of a codominant CAPS marker for allelic selection between canary yellow and red watermelon based on SNP in lycopene $\beta$-cyclase $(L C Y B)$ gene. Mol. Breed. 20:63-72.

Bang, H., S. Kim, D.I. Leskovar, A.R. Davis, and S.R. King. 2006. Duplication of the phytoene synthase gene in the carotenoid biosynthetic pathway of watermelon. HortScience 41:1007. (Abstract). Berman, J., U. Zorrilla-López, G. Farré, C. Zhu, G. Sandmann, R.M. Twyman, T. Capell, and P. Christou. 2015. Nutritionally important carotenoids as consumer products. Phytochem. Rev. 14:727-743.

Botella-Pavia, P. and M. Rodriguez-Concepcion. 2006. Carotenoid biotechnology in plants for nutritionally improved foods. Physiol. Plant. 126:369-381.

Brandi, F., E. Bar, F. Mourgues, G. Horváth, E. Turcsi, G. Giuliano, A. Liverani, S. Tartarini, E. Lewinsohn, and C. Rosati. 2011. Study of 
'Redhaven' peach and its white-fleshed mutant suggests a key role of CCD4 carotenoid dioxygenase in carotenoid and norisoprenoid volatile metabolism. BMC Plant Biol. 11:24.

Bu, J., Z. Ni, G. Aisikaer, Z. Jiang, Z.U. Khan, W. Mou, and T. Ying. 2014. Postharvest ultraviolet-C irradiation suppressed Psy-1 and $L c y$ - $\beta$ expression and altered color phenotype in tomato (Solanum lycopersicum) fruit. Postharvest Biol. Technol. 89:1-6.

Cazzonelli, C.I. and B.J. Pogson. 2010. Source to sink: Regulation of carotenoid biosynthesis in plants. Trends Plant Sci. 15:266-274.

Charnow, J.A. 2014. Greater intake of dietary lycopene may lower prostate cancer risk. Renal Urol. News 13:9.

Chayut, N., H. Yuan, S. Ohali, A. Meir, Y. Yeselson, V. Portnoy, Y. Zheng, Z. Fei, E. Lewinsohn, N. Katzir, A.A. Schaffer, S. Gepstein, J. Burger, L. Li, and Y. Tadmor. 2015. A bulk segregant transcriptome analysis reveals metabolic and cellular processes associated with orange allelic variation and fruit $\beta$-carotene accumulation in melon fruit. BMC Plant Biol. 15:274.

Chen, J., A. O'Donoghue, Y.F. Deng, B. Zhang, F. Kent, and T. O'Hare. 2014. The effect of lycopene on the PI3K/Akt signalling pathway in prostate cancer. Anticancer Agents Med. Chem. 14:800805 .

Clotault, J., D. Peltier, R. Berruyer, M. Thomas, M. Briard, and E. Geoffriau. 2008. Expression of carotenoid biosynthesis genes during carrot root development. J. Expt. Bot. 59:3563-3573.

Edwards, A.J., B.T. Vinyard, E.R. Wiley, E.D. Brown, J.K. Collins, P. Perkins-Veazie, R.A. Baker, and B.A. Clevidence. 2003. Consumption of watermelon juice increases plasma concentrations of lycopene and $\beta$-carotene in humans. J. Nutr. 133:1043-1050.

Fraser, P.D., S. Romer, C.A. Shipton, P.B. Mills, J.W. Kiano, N. Misawa, R.G. Drake, W. Schuch, and P.M. Bramley. 2002. Evaluation of transgenic tomato plants expressing an additional phytoene synthase in a fruit-specific manner. Proc. Natl. Acad. Sci. USA 99:1092-1097.

Gómez-García, M. del R. and N. Ochoa-Alejo. 2013. Biochemistry and molecular biology of carotenoid biosynthesis in chili peppers (Capsicum spp.). Intl. J. Mol. Sci. 14:19025-19053.

Grassi, S., G. Piro, J.M. Lee, Y. Zheng, Z. Fei, G. Dalessandro, J.J. Giovannoni, and M.S. Lenucci. 2013. Comparative genomics reveals candidate carotenoid pathway regulators of ripening watermelon fruit. BMC Genomics 14:781.

Grune, T., G. Lietz, A. Palou, A.C. Ross, W. Stahl, G. Tang, D. Thurnham, S.A. Yin, and H.K. Biesalski. 2010. $\beta$-Carotene is an important vitamin A source for humans. J. Nutr. 140:2268S-2285S. Guo, S., J. Liu, Y. Zheng, M. Huang, H. Zhang, G. Gong, H. He, Y. Ren, S. Zhong, Z. Fei, and Y. Xu. 2011. Characterization of transcriptome dynamics during watermelon fruit development: Sequencing, assembly, annotation and gene expression profiles. BMC Genomics 12:454.

Hashizume, T., I. Shimamoto, and M. Hirai. 2003. Construction of a linkage map and QTL analysis of horticultural traits for watermelon [Citrullus lanatus (Thunb.) Matsum \& Nakai] using RAPD, RFLP and ISSR markers. Theor. Appl. Genet. 106:779-785.

Holden, J.M., A.L. Eldridge, G.R. Beecher, I. Buzzard, S. Bhagwat, C.S. Davis, L.W. Douglass, S. Gebhardt, D. Haytowitz, and S. Schakel. 1999. Carotenoid content of US foods: An update of the database. J. Food Compos. Anal. 12:169-196.

Hwang, E.S., M. Stacewicz-Sapuntzakis, and P.E. Bowen. 2012. Effects of heat treatment on the carotenoid and tocopherol composition of tomato. J. Food Sci. 77:C1109-C1114.

Isaacson, T., G. Ronen, D. Zamir, and J. Hirschberg. 2002. Cloning of tangerine from tomato reveals a carotenoid isomerase essential for the production of $\beta$-carotene and xanthophylls in plants. Plant Cell 14:333-342.

Kang, B., W. Zhao, Y. Hou, and P. Tian. 2010. Expression of carotenogenic genes during the development and ripening of watermelon fruit. Scientia Hort. 124:368-375.

Kato, M., Y. Ikoma, H. Matsumoto, M. Sugiura, H. Hyodo, and M. Yano. 2004. Accumulation of carotenoids and expression of carotenoid biosynthetic genes during maturation in citrus fruit. Amer. Soc. Plant Biol. 134:824-837.

Kishimoto, S. and A. Ohmiya. 2009. Studies on carotenoids in the petals of Compositae plants. J. Jpn. Soc. Hort. Sci. 78:263-272.

Kong, Q., J. Yuan, L. Gao, S. Zhao, W. Jiang, Y. Huang, and Z. Bie. 2014. Identification of suitable reference genes for gene expression normalization in qRT-PCR analysis in watermelon. PLoS One 9: e90612.

Liu, S., P. Gao, X. Wang, A.R. Davis, A.M. Baloch, and F. Luan. 2015. Mapping of quantitative trait loci for lycopene content and fruit traits in Citrullus lanatus. Euphytica 202:411-426.

Livak, K.J. and T.D. Schmittgen. 2001. Analysis of relative gene expression data using real-time quantitative PCR and the $2^{-\Delta \Delta C}$ method. Methods 25:402-408.

Lu, S. and L. Li. 2008. Carotenoid metabolism: Biosynthesis, regulation, and beyond. J. Integr. Plant Biol. 50:778-785.

Lv, P., N. Li, H. Liu, H. Gu, and W.E. Zhao. 2015. Changes in carotenoid profiles and in the expression pattern of the genes in carotenoid metabolisms during fruit development and ripening in four watermelon cultivars. Food Chem. 174:52-59.

Nakkanong, K., J.H. Yang, and M.F. Zhang. 2012. Carotenoid accumulation and carotenogenic gene expression during fruit development in novel interspecific inbred squash lines and their parents. J. Agr. Food Chem. 60:5936-5944.

Nogueira, M., L. Mora, E.M. Enfissi, P.M. Bramley, and P.D. Fraser. 2013. Subchromoplast sequestration of carotenoids affects regulatory mechanisms in tomato lines expressing different carotenoid gene combinations. Plant Cell 25:4560-4579.

Ohmiya, A., S. Kishimoto, R. Aida, S. Yoshioka, and K. Sumitomo. 2006. Carotenoid cleavage dioxygenase (CmCCD4a) contributes to white color formation in chrysanthemum petals. Plant Physiol. 142:1193-1201.

Paine, J.A., C.A. Shipton, S. Chaggar, R.M. Howells, M.J. Kennedy, G. Vernon, S.Y. Wright, E. Hinchliffe, J.L. Adams, A.L. Silverstone, and R. Drake. 2005. Improving the nutritional value of golden rice through increased pro-vitamin A content. Nat. Biotechnol. 23:482487.

Perkins-Veazie, P., A. Davis, and J.K. Collins. 2012. Watermelon from dessert to functional food. Isr. J. Plant Sci. 60:395-402.

Perkins-Veazie, P., J.K. Collins, and S. Pair. 2002. Watermelon: Lycopene content changes with ripeness stage, germplasm, and storage. Cucurbitaceae 3:427-430.

Perkins-Veazie, P., J.K. Collins, A.R. Davis, and W. Roberts. 2006. Carotenoid content of 50 watermelon cultivars. J. Agr. Food Chem. 54:2593-2597.

Rao, A.V. and S. Agarwal. 2000. Role of antioxidant lycopene in cancer and heart disease. J. Amer. Coll. Nutr. 19:563-569.

Rockville. 2015. Consumers intrigued by functional foods. Merchandising Insights Consumables Rpt. 16:32.

Santos, C.A.F., D. Senalik, and P.W. Simon. 2005. Path analysis suggests phytoene accumulation is the key step limiting the carotenoid pathway in white carrot roots. Genet. Mol. Biol. 28:287-293.

Scarmo, S., B. Cartmel, H. Lin, D.J. Leffell, E. Welch, P. Bhosale, P.S. Bernstein, and S.T. Mayne. 2010. Significant correlations of dermal total carotenoids and dermal lycopene with their respective plasma levels in healthy adults. Arch. Biochem. Biophys. 504:34-39.

Sharoni, Y., K. Linnewiel-Hermoni, G. Zango, M. Khanin, H. Salman, A. Veprik, M. Danilenko, and J. Levy. 2012. The role of lycopene and its derivatives in the regulation of transcription systems: Implications for cancer prevention. Amer. J. Clin. Nutr. 96:1173S$1178 \mathrm{~S}$.

Stahl, W. and H. Sies. 2005. Bioactivity and protective effects of natural carotenoids. Biochim. Biophys. Acta 1740:101-107.

Sun, L., B. Yuan, M. Zhang, L. Wang, M. Cui, Q. Wang, and P. Leng. 2012. Fruit-specific RNAi-mediated suppression of SlNCED-1 increases both lycopene and $\beta$-carotene contents in tomato fruit. $\mathrm{J}$. Expt. Bot. 63:3097-3108. 
Tadmor, Y., S. King, A. Levi, A. Davis, A. Meir, B. Wasserman, J. Hirschberg, and E. Lewinsohn. 2005. Comparative fruit colouration in watermelon and tomato. Food Res. Intl. 38:837-841.

Tapiero, H., D.M. Townsend, and K.D. Tew. 2004. The role of carotenoids in the prevention of human pathologies. Biomed. Pharmacother. 58:100-110.

Tuan, P.A., J.K. Kim, N.I. Park, S.Y. Lee, and S.U. Park. 2011. Carotenoid content and expression of phytoene synthase and phytoene desaturase genes in bitter melon (Momordica charantia). Food Chem. 126:1686-1692.

Van Breemen, R.B. and N. Pajkovic. 2008. Multitargeted therapy of cancer by lycopene. Cancer Lett. 269:339-351.

Walter, M.H. and D. Strack. 2011. Carotenoids and their cleavage products: Biosynthesis and functions. Royal Soc. Chem. 28:663692.
Wei, X., C. Chen, Q. Yu, A. Gady, Y. Yu, G. Liang, and F.G. Gmitter, Jr. 2014. Comparison of carotenoid accumulation and biosynthetic gene expression between Valencia and Rohde Red Valencia sweet oranges. Plant Sci. 227:28-36.

Yoo, K.S., H. Bang, E.J. Lee, K. Crosby, and B.S. Patil. 2012. Variation of carotenoid, sugar, and ascorbic acid concentrations in watermelon genotypes and genetic analysis. Hort. Environ. Biotechnol. 53:552-560.

Yuan, H., J. Zhang, D. Nageswaran, and L. Li. 2015. Carotenoid metabolism and regulation in horticultural crops. Hort. Res. 2:15036.

Zhang, L., G. Ma, Y. Shirai, M. Kato, K. Yamawaki, Y. Ikoma, and H. Matsumoto. 2012. Expression and functional analysis of two lycopene $\beta$-cyclases from citrus fruits. Planta 236:1315-1325.

Zhao, W., P. Lv, and H. Gu. 2013. Studies on carotenoids in watermelon flesh. Agr. Sci. 4:13-20. 
Supplemental Table 1. Changes of lycopene and $\beta$-carotene accumulation in six watermelon accessions at seven time points of sampling during fruit development.

\begin{tabular}{|c|c|c|c|c|c|c|}
\hline \multicolumn{7}{|c|}{ Accumulation of lycopene and $\beta$-carotene $\left(\mu \mathrm{g} \cdot \mathrm{g}^{-1}\right)^{\mathrm{y}}$} \\
\hline Time points $(\mathrm{DAP})^{\mathrm{z}}$ & P4 [mean (SD)] & $\mathrm{C}[$ mean $(\mathrm{SD})]$ & W1 [mean (SD)] & P5 [mean (SD)] & $\mathrm{L}[$ mean $(\mathrm{SD})]$ & $\mathrm{M}[$ mean $(\mathrm{SD})]$ \\
\hline & \multicolumn{6}{|c|}{ Lycopene } \\
\hline 8 & $0.00(0) \mathrm{a}^{\mathrm{x}}$ & $0.00(0) \mathrm{a}$ & $0.00(0) \mathrm{a}$ & $0.00(0) \mathrm{a}$ & $0.00(0) \mathrm{a}$ & $0.00(0) \mathrm{a}$ \\
\hline 24 & $0.00(0) \mathrm{a}$ & $0.00(0) \mathrm{a}$ & $0.86(0.05) \mathrm{a}$ & $0.00(0) \mathrm{a}$ & $1.12(0.09) \mathrm{a}$ & $5.77(0.05) \mathrm{b}$ \\
\hline 32 & $0.00(0) \mathrm{a}$ & $0.00(0) \mathrm{a}$ & $1.49(0.04) b$ & $0.61(0.04) \mathrm{a}$ & $7.90(0.67) b$ & $28.70(1.03) \mathrm{c}$ \\
\hline 40 & $0.00(0) \mathrm{a}$ & $0.00(0) \mathrm{a}$ & $2.88(0.04) \mathrm{c}$ & $1.05(0.02) \mathrm{a}$ & $40.77(0.73) \mathrm{e}$ & $58.68(0.33) \mathrm{f}$ \\
\hline \multirow[t]{2}{*}{56} & $0.00(0) \mathrm{a}$ & $0.00(0) \mathrm{a}$ & $2.98(0.14) \mathrm{cd}$ & $12.60(0.78) \mathrm{d}$ & $33.40(1.19) \mathrm{c}$ & $54.30(1.18) \mathrm{d}$ \\
\hline & \multicolumn{6}{|c|}{$\beta$-Carotene } \\
\hline 8 & $0.00(0) \mathrm{a}$ & $0.00(0) \mathrm{a}$ & $0.00(0) \mathrm{a}$ & $0.00(0) \mathrm{a}$ & $0.00(0) \mathrm{a}$ & $0.00(0) \mathrm{a}$ \\
\hline 16 & $0.00(0) \mathrm{a}$ & $0.00(0) \mathrm{a}$ & $0.00(0) \mathrm{a}$ & $0.00(0) \mathrm{a}$ & $0.00(0) \mathrm{a}$ & $0.00(0) \mathrm{a}$ \\
\hline 24 & $0.00(0) \mathrm{a}$ & $0.00(0) \mathrm{a}$ & $0.10(0.01) \mathrm{a}$ & $0.00(0) \mathrm{a}$ & $0.00(0) \mathrm{a}$ & $0.00(0) \mathrm{a}$ \\
\hline
\end{tabular}

${ }^{\mathrm{z} D A P}=$ days after pollination.

'P4 = PI 459074, C = 'Cream of Saskatchewan', W1 = 'WM-Clr-1', P5 = PI 482255, L = 'LSW177', M = 'MSW28'.

${ }^{x}$ Any two means within a column not followed by the same letter are significantly different at $P \leq 0.05$ by Tukey's post hoc test.

Supplemental Table 2. Changes of gene expression in six watermelon accessions at seven time points of sampling during fruit development.

\begin{tabular}{|c|c|c|c|c|c|c|}
\hline \multicolumn{7}{|c|}{ Gene expression in six watermelon accessions ${ }^{y}$} \\
\hline Time points $(\mathrm{DAP})^{\mathrm{z}}$ & $\mathrm{P} 4[$ mean $(\mathrm{SD})]$ & $\mathrm{C}[$ mean $(\mathrm{SD})]$ & W1 [mean (SD)] & P5 [mean (SD)] & $\mathrm{L}[$ mean $(\mathrm{SD})]$ & $\mathrm{M}[$ mean $(\mathrm{SD})]$ \\
\hline & \multicolumn{6}{|c|}{$P S Y 1$ expression } \\
\hline 8 & $1.00(0.05) \mathrm{a}^{\mathrm{x}}$ & $1.00(0.02) \mathrm{a}$ & $1.00(0.07) \mathrm{a}$ & $1.00(0.01) \mathrm{a}$ & $1.00(0.05) \mathrm{a}$ & $1.00(0.09) \mathrm{a}$ \\
\hline 24 & $2.21(0.04) \mathrm{a}$ & $3.02(0.16) \mathrm{a}$ & $12.90(0.86) \mathrm{c}$ & $9.10(0.53) \mathrm{b}$ & $9.86(0.82) b$ & $11.83(0.60) \mathrm{c}$ \\
\hline 32 & $2.34(0.22) \mathrm{a}$ & $3.43(0.29) \mathrm{a}$ & $13.44(0.88) \mathrm{c}$ & $12.16(1.26) \mathrm{c}$ & $7.60(0.50) b$ & $28.41(2.09) \mathrm{d}$ \\
\hline 40 & $8.15(0.75) b$ & $5.66(0.53) \mathrm{a}$ & $11.50(0.36) \mathrm{c}$ & $13.86(0.78) \mathrm{d}$ & $17.18(1.05) \mathrm{e}$ & $16.35(0.48) \mathrm{e}$ \\
\hline 56 & $3.18(0.03) \mathrm{a}$ & $2.92(0.10) \mathrm{a}$ & $7.32(0.35) \mathrm{c}$ & $9.35(0.64) \mathrm{d}$ & $5.79(0.25) b$ & $14.55(0.45) \mathrm{e}$ \\
\hline
\end{tabular}

$\begin{array}{cll}8 & 1.00(0.05) \mathrm{a} & 1.00(0.08) \mathrm{a} \\ 16 & 3.01(0.26) \mathrm{b} & 0.15(0.02) \mathrm{a} \\ 24 & 0.41(0.03) \mathrm{ab} & 0.54(0.03) \mathrm{b} \\ 32 & 0.40(0.03) \mathrm{b} & 0.25(0.02) \mathrm{a} \\ 40 & 0.26(0.02) \mathrm{a} & 2.11(0.10) \mathrm{c} \\ 48 & 0.64(0.04) \mathrm{c} & 0.17(0.01) \mathrm{a} \\ 56 & 0.19(0.01) \mathrm{a} & 0.25(0.01) \mathrm{a}\end{array}$

\section{PSY2 expression}

$\begin{array}{rll}8 & 1.00(0.03) \mathrm{a} & 1.00(0.10) \mathrm{a} \\ 16 & 0.81(0.05) \mathrm{a} & 0.76(0.07) \mathrm{a} \\ 24 & 0.55(0.08) \mathrm{a} & 1.25(0.11) \mathrm{b} \\ 32 & 0.52(0.08) \mathrm{a} & 1.71(0.09) \mathrm{b} \\ 40 & 0.98(0.03) \mathrm{a} & 1.41(0.10) \mathrm{a} \\ 48 & 1.27(0.10) \mathrm{ab} & 1.02(0.09) \mathrm{a} \\ 56 & 1.87(0.01) \mathrm{b} & 1.50(0.05) \mathrm{a} \\ & & \\ 8 & & \\ 16 & 1.00(0.07) \mathrm{a} & 1.00(0.02) \mathrm{a} \\ & 1.05(0.08) \mathrm{b} & 0.44(0.02) \mathrm{a}\end{array}$

$1.01(0.06) \mathrm{a}$

$4.98(0.20) \mathrm{c}$

$3.42(0.12) \mathrm{b}$

$5.23(0.31) \mathrm{d}$

$12.50(0.58) \mathrm{d}$

$9.75(0.18) \mathrm{e}$

$2.64(0.19) \mathrm{c}$

$1.00(0.09) \mathrm{a}$ $2.11(0.14) \mathrm{d}$

$\begin{array}{ll}1.00(0.02) \mathrm{a} & 1.00(0.06) \mathrm{a} \\ 0.34(0.01) \mathrm{a} & 4.48(0.24) \mathrm{c} \\ 0.32(0.02) \mathrm{a} & 1.31(0.07) \mathrm{c} \\ 0.24(0.02) \mathrm{a} & 2.04(0.02) \mathrm{d} \\ 0.26(0.01) \mathrm{a} & 0.67(0.03) \mathrm{b} \\ 0.36(0.00) \mathrm{b} & 0.64(0.02) \mathrm{c} \\ 0.42(0.04) \mathrm{b} & 1.64(0.13) \mathrm{d}\end{array}$

$1.00(0.04) \mathrm{a}$

$2.65(0.11) \mathrm{b}$

$1.72(0.10) \mathrm{d}$

$0.41(0.03) \mathrm{b}$

$3.66(0.32) \mathrm{d}$

$1.76(0.03) \mathrm{e}$

$1.14(0.04) \mathrm{c}$

PDS expression

$1.00(0.09) \mathrm{a}$ $0.46(0.04) \mathrm{a}$ $0.48(0.02) \mathrm{b}$ $0.53(0.05) \mathrm{c}$ $0.13(0.01) \mathrm{a}$ $1.22(0.05) \mathrm{d}$ $1.05(0.01) \mathrm{c}$

$1.00(0.03) \mathrm{a}$ $2.45(0.20) \mathrm{b}$ $2.55(0.09) \mathrm{b}$ $1.34(0.13) \mathrm{b}$ $2.39(0.04) \mathrm{b}$ $2.20(0.03) \mathrm{c}$ $3.55(0.14) \mathrm{d}$

\section{$Z D S$ expression}

$1.00(0.09) \mathrm{a} \quad 1.00(0.07) \mathrm{a}$ $0.49(0.01) \mathrm{a} \quad 1.59(0.12) \mathrm{c}$
$1.00(0.04) \mathrm{a}$ $1.41(0.09) \mathrm{c}$ 


\begin{tabular}{|c|c|c|c|c|c|c|}
\hline \multicolumn{7}{|c|}{ Gene expression in six watermelon accessions ${ }^{y}$} \\
\hline Time points $(\mathrm{DAP})^{\mathrm{z}}$ & P4 [mean (SD)] & $\mathrm{C}[$ mean $(\mathrm{SD})]$ & W1 [mean (SD)] & P5 [mean (sD)] & $\mathrm{L}[$ mean $(\mathrm{SD})]$ & $\mathrm{M}[$ mean (SD)] \\
\hline 24 & $1.29(0.09) \mathrm{d}$ & $1.81(0.05) \mathrm{e}$ & $0.65(0.01) \mathrm{b}$ & $0.82(0.06) \mathrm{c}$ & $0.48(0.05) \mathrm{a}$ & $1.86(0.06) \mathrm{e}$ \\
\hline 40 & $0.68(0.06) \mathrm{b}$ & $6.20(0.22) \mathrm{d}$ & $0.29(0.02) \mathrm{a}$ & $0.68(0.03) \mathrm{b}$ & $1.18(0.05) \mathrm{c}$ & $1.39(0.05) \mathrm{c}$ \\
\hline 48 & $0.99(0.07) \mathrm{c}$ & $0.36(0.02) \mathrm{a}$ & $0.56(0.01) \mathrm{a}$ & $1.44(0.08) \mathrm{d}$ & $0.70(0.03) \mathrm{b}$ & $1.55(0.13) \mathrm{d}$ \\
\hline 56 & $0.54(0.05) \mathrm{c}$ & $0.36(0.02) \mathrm{ab}$ & $0.30(0.02) \mathrm{a}$ & $0.71(0.02) \mathrm{d}$ & $0.44(0.01) \mathrm{bc}$ & $1.37(0.10) \mathrm{e}$ \\
\hline 8 & $1.00(0.09) \mathrm{a}$ & $1.00(0.08) \mathrm{a}$ & $1.00(0.02) \mathrm{a}$ & $1.00(0.05) \mathrm{a}$ & $1.00(0.07) \mathrm{a}$ & $1.00(0.07) \mathrm{a}$ \\
\hline 16 & $0.40(0.01) \mathrm{a}$ & $1.02(0.08) b$ & $0.42(0.03) \mathrm{a}$ & $0.29(0.03) \mathrm{a}$ & $2.18(0.12) \mathrm{c}$ & $1.17(0.02) b$ \\
\hline 24 & $2.82(0.20) \mathrm{e}$ & $1.03(0.03) \mathrm{b}$ & $1.28(0.04) \mathrm{c}$ & $0.75(0.05) \mathrm{a}$ & $0.88(0.07) a b$ & $1.63(0.12) \mathrm{d}$ \\
\hline 32 & $1.12(0.04) b$ & $1.23(0.04) \mathrm{b}$ & $0.52(0.03) \mathrm{a}$ & $1.11(0.09) \mathrm{b}$ & $2.30(0.17) \mathrm{c}$ & $2.61(0.24) \mathrm{c}$ \\
\hline 40 & $2.60(0.27) \mathrm{c}$ & $1.39(0.07) \mathrm{b}$ & $1.57(0.15) \mathrm{b}$ & $0.78(0.06) \mathrm{a}$ & $2.38(0.10) \mathrm{c}$ & $3.82(0.33) \mathrm{d}$ \\
\hline 8 & $1.00(0.08) \mathrm{a}$ & $1.00(0.07) \mathrm{a}$ & $1.00(0.09) \mathrm{a}$ & $1.00(0.09) \mathrm{a}$ & $1.00(0.07) \mathrm{a}$ & $1.00(0.07) \mathrm{a}$ \\
\hline 16 & $1.69(0.12) \mathrm{c}$ & $0.78(0.04) \mathrm{a}$ & $1.33(0.08) b$ & $1.71(0.13) \mathrm{c}$ & $0.72(0.04) \mathrm{a}$ & $0.74(0.04) \mathrm{a}$ \\
\hline 24 & $1.43(0.06) b$ & $1.77(0.09) \mathrm{c}$ & $5.47(0.08) \mathrm{d}$ & $1.42(0.11) b$ & $0.28(0.03) \mathrm{a}$ & $1.67(0.07) \mathrm{c}$ \\
\hline 32 & $1.60(0.13) \mathrm{c}$ & $1.53(0.14) b c$ & $3.20(0.11) \mathrm{d}$ & $1.29(0.07) b$ & $0.45(0.03) \mathrm{a}$ & $0.67(0.04) \mathrm{a}$ \\
\hline 40 & $1.22(0.09) \mathrm{ab}$ & $1.38(0.09) \mathrm{ab}$ & $2.39(0.16) \mathrm{d}$ & $1.43(0.06) \mathrm{b}$ & $1.78(0.10) \mathrm{c}$ & $1.11(0.05) \mathrm{a}$ \\
\hline 48 & $1.18(0.06) \mathrm{a}$ & $1.57(0.12) \mathrm{c}$ & $2.95(0.07) \mathrm{d}$ & $1.52(0.11) b c$ & $1.27(0.11) \mathrm{ab}$ & $1.72(0.12) \mathrm{c}$ \\
\hline \multirow[t]{2}{*}{56} & $1.34(0.05) \mathrm{b}$ & $1.67(0.10) \mathrm{c}$ & $3.04(0.17) \mathrm{e}$ & $2.00(0.02) \mathrm{d}$ & $0.23(0.02) \mathrm{a}$ & $1.67(0.14) \mathrm{c}$ \\
\hline & \multicolumn{6}{|c|}{ NCED1 expression } \\
\hline 8 & $1.00(0.05) \mathrm{a}$ & $1.00(0.03) \mathrm{a}$ & $1.00(0.09) \mathrm{a}$ & $1.00(0.08) \mathrm{a}$ & $1.04(0.07) \mathrm{a}$ & $1.00(0.03) \mathrm{a}$ \\
\hline 16 & $2.97(0.14) \mathrm{d}$ & $0.28(0.02) \mathrm{a}$ & $0.57(0.06) \mathrm{b}$ & $5.44(0.16) \mathrm{e}$ & $0.96(0.05) \mathrm{c}$ & $1.10(0.11) \mathrm{c}$ \\
\hline 16 & $1.98(0.16) \mathrm{c}$ & $0.15(0.01) \mathrm{a}$ & $0.50(0.05) \mathrm{ab}$ & $7.31(0.29) \mathrm{d}$ & $0.75(0.05) \mathrm{b}$ & $0.44(0.04) \mathrm{ab}$ \\
\hline 24 & $0.20(0.00) \mathrm{a}$ & $6.55(0.16) \mathrm{e}$ & $0.52(0.01) b c$ & $1.34(0.13) \mathrm{d}$ & $0.37(0.02) \mathrm{ab}$ & $0.62(0.02) \mathrm{c}$ \\
\hline 32 & $1.28(0.09) \mathrm{b}$ & $4.06(0.26) \mathrm{e}$ & $2.03(0.06) \mathrm{c}$ & $1.13(0.09) \mathrm{d}$ & $0.31(0.01) \mathrm{a}$ & $2.47(0.06) \mathrm{d}$ \\
\hline 40 & $3.54(0.16) b$ & $0.77(0.03) \mathrm{a}$ & $5.53(0.25) \mathrm{c}$ & $2.67(0.27) \mathrm{b}$ & $7.98(0.75) \mathrm{d}$ & $3.31(0.22) b$ \\
\hline 48 & $7.44(0.57) b$ & $10.60(0.47) \mathrm{c}$ & $6.71(0.05) b$ & $17.57(0.35) \mathrm{d}$ & $18.33(0.84) \mathrm{d}$ & $5.00(0.29) \mathrm{a}$ \\
\hline 56 & $2.85(0.18) \mathrm{a}$ & $3.48(0.16) \mathrm{a}$ & $13.88(0.32) \mathrm{c}$ & $18.18(0.87) \mathrm{d}$ & $2.82(0.16) \mathrm{a}$ & $7.51(0.38) b$ \\
\hline
\end{tabular}

${ }^{\mathrm{z} D A P}=$ days after pollination.

'P4 = PI 459074, C = 'Cream of Saskatchewan', W1 = 'WM-Clr-1', P5 = PI 482255, L = 'LSW177', M = 'MSW28'.

xAny two means within a row not followed by the same letter are significantly different at $P \leq 0.05$ by Tukey's post hoc test. 